\title{
Product development sourcing over technology life-cycle
}

\section{Marzieh Shahmarichatghieh*, Janne Härkönen, Harri Haapasalo and Arto Tolonen}

\author{
Industrial Engineering and Management, \\ Faculty of Technology, \\ University of Oulu, \\ P.O. Box 4610, FI-90014, Finland \\ Email: Marzieh.shahmari@oulu.fi \\ Email: Janne.harkonen@oulu.fi \\ Email: Harri.haapasalo@oulu.fi \\ Email: Arto.tolonen@oulu.fi \\ *Corresponding author
}

\begin{abstract}
Product development sourcing is vital due to the significant impact on company and product success. Different technology life-cycle (TLC) stages also necessitate product development sourcing to focus accordingly. Understanding the dynamics of product development sourcing over TLC's can prove beneficial. This study analyses product development sourcing strategies through three strategy formulating theories of transaction cost theory, knowledge-based theory, and resource-based theory over TLC stages. Three sourcing strategies of outsourcing, strategic acquisitions, and strategic alliances are considered. The topic is approached both by analysing literature and applying inductive logic for analysing product development sourcing over three technology generations in the context of an important player in the high-tech infrastructure business. A framework is introduced where product development activities emphasis and sourcing strategies' focus is presented over TLC, indicating the priorities in different situations. Contribution is provided by analysing motivations behind product development sourcing decisions over three technology generations' life-cycles.
\end{abstract}

Keywords: technology life-cycle; product development sourcing; sourcing strategies; outsourcing; alliances; acquisitions; procurement management; transaction cost theory; TCT; resource-based theory; knowledge-based theory.

Biographical notes: Marzieh Shahmarichatghieh is a doctoral student in the Department of Industrial Engineering and Management in University of Oulu.

Janne Härkönen is a Post-Doctoral Research Fellow in the Industrial Engineering and Management Department of University of Oulu.

Harri Haapasalo is a Professor and the Head of Industrial Engineering and Management Department and Dean of Research in Faculty of Technology at University of Oulu. 
Arto Tolonen is a doctoral student in the Department of Industrial Engineering and Management in the University of Oulu.

\section{Introduction}

Understanding the dynamics of technologies and the impacts of technological developments on company functions over technology life-cycles can be beneficial for company managers. Nevertheless, technologies are necessary, but not sufficient for product success (Clark and Fujimoto, 1991). The product and service success is based on the adequate integration of technology and markets (Betz, 2011; Wieland et al., 2016). Rapid changes in technologies and the frequent new product introductions force companies to consider different ways of remaining ahead of competition and to be flexible (Bettis and Hitt, 1995). Even very large companies such as Nokia, Blackberry and Kodak who once were extremely successful have failed due to making wrong choices (Fenech and Tellis, 2016; Mui, 2012; Shih, 2016). Right actions at the relevant life-cycle stages are necessary. Also, the dynamic transition of products through various technology life-cycle stages and active management of products are important (Seifert et al., 2015; Tolonen et al., 2015a, 2015b). Hence, different company functions will impact the success of product development over technology life-cycles.

Product development sourcing in competitive situations across technology life-cycles can be much more challenging than regular sourcing. Sourcing is too often seen as a defensive operational measure with a scorekeeping orientation to reduce costs, improve returns, and increase brand share, not ideal for informed product development sourcing decisions (Barragan et al., 2003). Product development sourcing decisions have both direct and indirect effects on the company, some of which are more complicated to measure than others (Sundquist et al., 2016). Hence, it is in the interest of companies to consider their competitive position adequately and act accordingly. Particularly, the role of knowledge and capabilities is emphasised in product development sourcing (Chesbrough et al., 2006). There are different studies on product development sourcing strategies (Ahmed et al., 2014; Brunswicker and Vanhaverbeke, 2014; Eltantawy et al., 2014). For example, Søndergaard and Ahmed-Kristensen (2015) point how sourcing decisions with cost, knowledge and capability considerations are relevant, whereas decision making is not always structured, and can be based more on priorities than planning. However, the knowledge and technological capabilities have not been studied in conjunction with product development sourcing strategies based on technology maturity levels over technology life-cycles.

Technology life-cycles have been studied from different viewpoints with various stages (e.g. Abernathy and Utterback, 1978; Achilladelis et al., 1990; Achilladelis, 1993; Anderson and Tushman, 1990; Erickson et al., 1990; Ford and Ryan, 1981; Linden and Fenn, 2003; Little, 1981; Moore, 2011; Rogers, 2010; Routley et al., 2013; Watts and Porter, 1997). Nevertheless, for simplicity, we utilise the technology life-cycle model by Khalil (2000) as the basis of investigating technology maturity levels due to the fact that it contains the majority of phases also present in the other models. Previous literature has not adequately discussed the product development characteristics in conjunction with sourcing strategy factors along technology maturity levels over technology life-cycles. 
Product development sourcing strategies can be divided into various groups (e.g. Chiesa and Manzini, 1998; Kotabe and Helsen 1998; Kotabe, 1992), while in this study we chose outsourcing, strategic alliances, and strategic acquisition based on the level of company integration. Different strategy models define the driving factors for each sourcing strategy (e.g. Chiesa and Manzini, 1998; Das and Teng, 2000; Jacobides and Billinger, 2006; Madhok, 1997; Parkhe, 1993). Nevertheless, Kistruck et al. (2016) suggest that it is not only the factors that influence sourcing decisions that are relevant, but also the appropriateness and combination of certain factors. Hence, it may be challenging to obtain a comprehensive understanding over sourcing strategies in different stages of technology life-cycles. Hence, in order to improve the transparency of sourcing strategies, they are investigated under three strategy models requirements in this study, including: transaction cost theory (TCT), knowledge-based theory (KBT), and resourcebased theory (RBT).

In this study product development sourcing strategies are studies based on technology maturity levels within a technology life-cycle. Product development specifications and sourcing strategy factors are discussed along technology maturity levels over the technology life-cycle. In order to find the drivers for selecting each suitable sourcing strategy, three different models are used, namely: TCT, knowledge-based theory, and resource-based theory. A frame is attempted to formulate for evaluating product development sourcing strategies in different situations based on technology maturity levels. The experiences and data of a well-known high-tech infrastructure producer are utilised as the empirical basis of this study due to their experience in concurrently working on three different technology generations and the company being one of the leaders in their industry. Studying multiple technology generations within the same company provides the opportunity to obtain more realistic insights on product development sourcing in a market where the technologies are competing against each other.

The research questions are formulated as follows:

RQ1 How can product development sourcing strategies are mapped over a technology life-cycle?

RQ2 What are the main drivers for choosing product development sourcing strategies based on technology maturity levels along technology life-cycles?

\section{Literature review}

\subsection{Technology life-cycle}

Technology life-cycle is a pattern of different aspects of technologies over time (Albert et al., 2015; Khalil, 2000). Many models have been created based on the technology lifecycle (TLC) definition (e.g. Abernathy and Utterback, 1978; Achilladelis et al., 1990; Achilladelis, 1993; Anderson and Tushman, 1990; Erickson et al., 1990; Ford and Ryan, 1981; Khalil, 2000; Linden and Fenn, 2003; Little, 1981; Moore, 2011; Rogers, 2010; Routley et al., 2013; Watts and Porter, 1997).

In this study, one of the most generic technology life-cycle models by Khalil (2000) is used to map technological changes. The model was firstly built by Fisher and Pry (1971) with the aim of technology forecasting. The TLC by Khalil (2000) illustrates 
technology performance patterns with four phases: embryonic, growth, maturity, and aging. Although Khalil's model is one of the most utilised technology life-cycle models, some criticism have been presented, for example lack of performance parameters to represent economical and technical trend (e.g. Asthana, 1995; Ernst, 1997; Gao et al., 2013; Lee and Nakicenovic, 1989; Murmann and Frenken, 2006). Therefore, besides considering Khalil's model as the foundation of this study, the pieces of literature on other technology life-cycle models are appreciated.

In the embryonic phase, no defined technologies or products exist while product development activities are mostly radical and less practical (Albert et al., 2015; Erickson et al., 1990; Gao et al., 2013; Little, 1981). Time-to-market is very important (O'Reilly and Tushman, 2013), as there are no defined technologies or products in the market, process of standard establishment is in progress. Companies compete to have a bigger share of standards in the market (Abernathy and Utterback, 1978). Additionally, there is an enormous amount of uncertainty involved in the product development activities (Amoroso et al., 2015).

With the first appearance of the new products or technologies in the market, the technology enters the growth phase (Ford and Ryan, 1981; Gao et al., 2013; Moore, 2002). The technology concept is defined and technology applications are found in the previous phase, while there are still lots of breakthrough innovations at this stage (Haupt et al., 2007). Firstly, the new technology should be modified to be compatible with current infrastructure in the market (Ford and Ryan, 1981), secondly more technology applications should be found (Abernathy and Utterback, 1978). As the functionality and performance of the product utilising the technology is not ideal, the competition is on performance levels and functionality (Albert et al., 2015; Christensen et al., 2001). Timeto-market is still important (O'Reilly and Tushman, 2013).

In the middle of growth phase, due to high uncertainty (Park et al., 2015) and expensive unreliable product technologies (Ford and Ryan, 1981), the technology might experience the gap in the life-cycle, or as often referred to the chasm (Moore, 2002). Market related factors such as the hesitation of pragmatist customers is typical at this stage of growth. Therefore, the companies need to leverage performance (Abernathy and Utterback, 1978) and reduce costs (Albert et al., 2015), besides marketing strategies such as segmentation (Moore, 2002), to pass the chasm and return to the growth stage even as a more powerful actor.

The maturity phase entails technology performance levels becoming more standard and constant, while technology starts approaching its limitations and requires greater efforts to achieve improvements (Albert et al., 2015; Christensen, 1992). As the competitors remaining in the game at this stage have sufficient knowledge, the competition goes through cost, customisation and whole product+1 (Lilischkis, 2013; Moore, 1998). Thus as there is high competition in the market (Albert et al., 2015; O'Reilly and Tushman, 2013) by mostly established companies (Asthana, 1995). Product development activities at this stage tend to involve variation, customisation (Anderson and Tushman, 1990), and cost reduction (Abernathy and Utterback, 1978).

Finally, when the technological performance becomes more constant and there is no significant room for performance improvement, the technology starts declining and gets aged (Ford and Ryan, 1981). Technology performance may be at the highest by many TLC indicators at this stage (Gao et al. 2013). Processes are also in the highest level of 
efficiency but flexibility and innovation trends are decreasing (Abernathy and Utterback, 1978). Moreover, cost reduction is the most apparent need of laggard customers (Moore, 2002) beside the fact that the laggard group of customers are not very interested in using complicated technologies (Rogers, 2010) and prefer to have simple and more user friendly products, which can also be a competitive strategy at this point (Moore, 1998).

\subsection{Product development sourcing strategies}

Three external product development sourcing strategies are discussed, including outsourcing, strategic alliances and strategic company acquisition. These sourcing strategies have distinct levels of integration between the companies. Each of these sourcing strategies can be linked to various governance models and structures which are out of the scope of this study.

\subsubsection{Outsourcing}

Outsourcing product development is seen as implication, process and sourcing of innovation from outside of the company (Suarez-Villa and Rama, 1996). Additionally, outsourcing can be seen as external technological activities, where the company just buys the result (Chiesa and Manzini, 1998), result which can be investigated from various viewpoints. As the first priority for many organisations is being beneficial, with lower costs, many studies have been realised based on the impacts of outsourcing on cost reduction (e.g. Afuah, 2001; Leiblein and Miller, 2003; Masten et al., 1991; Monteverde, 1995; Rothaermel and Deeds, 2006; Spithoven and Teirlinck, 2015).

On the other hand, the boldest aspect of product development sourcing is knowledge transfer that different studies have tried to address while discussing outsourcing in product development (e.g. Afuah, 2001; Cohen and Levinthal, 1990; Gupta and Polonsky, 2014; McGrath and McMillan, 2000; Rothaermel and Deeds, 2006). Many researchers have shown that knowledge transfer by outsourcing can be easy and fast (Lawson et al., 2014; Torvinen et al., 2014; Zhao et al., 2014), while simultaneously various studies have illustrated the negative impacts of knowledge transfer by outsourcing, such as opportunistic behaviour (Bhattacharya et al., 2015; Handley and Angst, 2014), and organisational costs compared to internalising (Jacobides and Billinger, 2006). On the other hand, Outsourcing combined with globalisation or segmentation of business processes, involving people from internal and external organisations may hamper the product quality as more complex communication is required ( $\mathrm{Ng}$ et al. 2012).

Beside the fact that the ultimate aim of sourcing in any organisation is optimised allocation of resources (Hamel and Prahalad, 1994; Quinn, 2013; Teece et al., 1997), many studies have tried to investigate product development outsourcing based on resource perspective (e.g. Cassiman and Veulgeres, 2000; Kozlenkova et al., 2014). Moreover, different studies recommend outsourcing product development only partially to keep the company size, and enjoy the benefits of external resources such as materials testing or prototyping (Mowery and Rosenberg, 1989). 


\subsubsection{Strategic alliances}

Strategic alliances are defined as sharing the resources of different companies to gain shared innovative value (Chiesa and Manzini, 1998). Different studies introduce motivations for forming strategic alliances including, internationalisation (Brouthers et al., 2014; Yoshino and Rangan, 1995), technological needs (Gilsing et al., 2015; Hagerdoorn, 1993; Tyler and Steensma, 1998) and uncertainty (Collet and Philippe, 2014; Dickson and Weaver, 1997). Strategic alliances are also presented as a sourcing lever to optimise supply relationships (Hesping and Schiele, 2016).

For example Gulati (1995) recommends building strategic alliances when there are medium levels of costs that relate to transactions, ones that are enough to choose outsourcing. Other studies focus on aspects such as continuity (Olk and Young, 1997), stability (Parkhe, 1993), and flexibility (Young-Ybarra and Wiersema, 1999), all of which, in a cost centric manner. There are also various studies that try to investigate strategy, estimate the hazards and build adequate models to overcome risks, or prevent risks (e.g. Buvik and Halskau, 2016; Parkhe, 1991; Galanter, 1981; Oumlil and Williams, 2011; Williamson, 1983). For example, Parkhe (1993) built a model for gaining the best strategic alliance for preventing opportunistic behaviour. Moreover, Kogut (1988) suggest building strategic alliances rather than relying on other means of sourcing, in situations when the uncertainty and asset specificity are high and outsourcing and auditing the performance are not easy.

Companies requires to have special knowledge, capabilities and know-how to transform technologies into products and sell them to customers (Amit and Schoemaker, 2013; Teece et al., 1997), whereas gaining the knowledge is a complex, time consuming and an expensive task. Hence, many companies enter allies to gain what is needed to fill the gap between their own available knowledge and the required know-how (George et al., 2002; Hagerdoorn, 1993; Patzelt et al., 2008; Rothaermel and Deeds, 2006; Wei et al., 2000). This type of learning and knowledge transfer is dependent on factors such as absorptive capacity (Nelson and Winter, 2009; Powell et al., 1996), which can be seen to be based on a company's internal capabilities (Leiblein and Miller, 2003; Mayer and Nickerson, 2005).

In situations when a resource is critical to the market and external companies own it, and while the resource is not separable from other assets, a strategic alliance can be a suitable strategy (Ramanathan et al., 1997). Madhok (1997) adds the fact that developing such critical resources internally could be costly and timely for the company. Therefore, companies tend to form strategic alliances in case of critical resources when the resource characteristics and company organisational governance are influential enough to build strategic alliances (Das and Teng, 2000).

\subsubsection{Strategic company acquisition}

Companies typically acquire other companies to access certain technologies or technology competencies (Chiesa and Manzini, 1998). Additionally, Chatterji (1996) argues that large companies buy smaller ones to develop particular technologies. Other reasons, such as faster time-to-market in product development can be considered among the reasons for strategic acquisitions (Chatterji, 1996; Chiesa and Manzini, 1998; Roberts and Berry, 1984). The literature view acquisitions mostly from a geographical viewpoint and analyse them from the viewpoint of broadening, or optimising the geographical 
market (Harrison et al., 1991). Particularly, actors in the emerging markets acquire technologies to remain competitive in their domestic markets and if they have global ambitions, to compete globally (Sharma and Jha, 2016).

Kogut (1988) believes that the reason of acquiring a company lies in other factors than the costs of transaction, while Oster (1990) argues that either acquisition should either be seen as a profitable bargain or as a source of more efficient processes. Hennart and Reddy (1997) present two factors for choosing acquisition: increased efficiency and desirability of the company to be acquired, they also mention some obstacles of strategic acquisition success, including established organisational culture and pre-hired labour. Also Stettner and Lavie (2014) introduce drivers for acquisitions, including cost, market power and technological synergy. Brand name and customer acquisition are also among the driving factors of acquisition strategy (Yip, 1982). Knowledge acquisition is a known reason for acquisitions (Ferreira et al., 2014). The knowledge to be acquired can be divided into general knowledge of local economy and product specific knowledge (Hennart, 1988). The internal capabilities of the buyer company also play a crucial role in the acquisitions, as the new resources should be managed and aligned perfectly with the internal elements of the buyer organisation to be beneficial (Hennart and Raddy; 1997; Stettner and Lavie, 2014; Wilson, 1980; Zejan, 1990).

\subsection{Driving factors for product development sourcing over TLC}

Three company strategy indicator models were selected to analyse different sourcing strategies over a technology life-cycle based on their characteristics, the models include: TCT, knowledge-based theory, and resource-based theory. This tackles the lack in diversity in theories used as Sucky and Durst (2013) have emphasised the lack of diversity as the shortcoming of many studies that focus on a single theory. It is particularly the technological change and the pace of development in high-tech why companies require perspectives for the build, borrow or buy decisions (Capron and Mitchell, 2013). In this section, relevant factors and the characteristics of each theory are discussed.

\subsubsection{Transaction cost theory}

There are several methods that can be used to analyse sourcing strategies. The oldest and most known theory that is based on cost planning is developed by Williamson (1983, 1991). Generally, from TCT viewpoint there are two different cost groups that can conclude total costs: production cost and transaction cost (Williamson, 1991). The production cost is the cost of adding value in the perfect market circumstances, while the transaction cost comes from any failures that can be made by the market (Williamson, 1991).

TCT can be applied to approach sourcing decisions due to its uses as an explanator. The question may be formulated as of whether it is more cost-efficient to use the market and outsource opposed to relying on hierarchy and utilise in-house provision, depending on the nature of the tasks being considered (Williamson, 1981). Cost savings of outsourcing would deteriorate if investments are necessary to perform the task as investments would decrease production cost savings, but also lead into opportunistic situations (Williamson, 1981). Transaction costs would rise due to any efforts to protect against opportunistic behaviour. According to TCT, opportunistic behaviour is possible to 
be prevented better through hierarchies than in exchange relationships with external companies (Williamson, 1975). The decision of sourcing could be market acquisition (outsourcing), hierarchy (internalising) or hybrid (building allies), which as Coase (2007), and later Kogut (1988) argue that the production cost could be reduced by outsourcing, while the transaction costs can increase dramatically by using allies or market integration. Therefore, not only the production costs of different sourcing strategies should be evaluated, but also the transaction costs should be found (Das and Teng, 2000). Williamson $(1983,1991)$ classified the transaction cost driver factors into three groups: asset specificities, frequency and uncertainty. As an example of more advanced considerations, Sharma (2016) has developed a strategic sourcing decision model that incorporates also risk elements aside cost elements to support sourcing decisions, where transaction cost is considered as one of the major cost factors. It is the uncertainty surrounding a transaction that is critical also from the perspective of forming alliances as companies have to plan for potential contingencies and the cost of transaction tends to rise (Williamson, 1979). Particularly in high-tech collaborations, alliance partners are not necessarily aware of the complex interactions involving many technical processes and the impact of these interactions on collaborative outcomes (Fleming, 2001). Trust being an important driver for alliance performance, Meier et al. (2016) has distinguished between different mechanisms. On the other hand, contractual governance in the form of detailed contracts that cover contingencies is seen to safeguard against opportunism concerns in strategic alliances (Mayer and Argyres, 2004). Acquisition transactions, on the other hand, may take place on both the buy and sell sides in strategic acquisitions, nevertheless particularly overcoming cross-border barriers may come with significant transaction costs (Holloway et al. 2016).

Strategic sourcing have previously been seen from different perspectives and the decision making structures are built according to diverse factors (Heide and Weiss, 1995), whereas from the product perspective the interactions of different products via for example cannibalisation are seen to weaken the robustness of the methods (Rumelt, 1995). Also, Ghoshal and Moran (1996) urge to caution against applying TCT logic for normative purposes, whilst view it useful for simplifying assumptions and explaining practice. Williamson (1991) critiques the theory by himself by arguing that in long-term contracting the company would result in being too dependent on the suppliers because the knowledge and the internal capabilities would be forgotten according to the TCT. Nevertheless, TCT appears not to have been applied on product development sourcing decisions over the technology life-cycle stages in the previous literature.

\subsubsection{Knowledge-based theory}

Knowledge-based theory focuses on the competence of people as they are seen as the only true agents of business where assets, both tangible and intangible are results of human action (Sveiby, 2001). The knowledge and the know-how are seen as documented assets like any other tangible assets of the company. The theory tries to allocate knowledge and know-how in a more efficient way to add the most value (Grant, 1996). Cross-functional capabilities such as product development reflect the strategic importance and managerial challenge of capabilities that require integrating specialists with knowledge (Clark and Fujimoto, 1992; Grant, 1996). Competitive advantage relates to how well a company creates, stores, and applies knowledge (Drucker, 1978). 
Knowledge-based theory, has been applied in different areas such as intellectual strategic planning (Rossi et al., 2016) and knowledge management area (Calvo-Mora et al., 2015).

Knowledge-based reasoning predicts perhaps even tautologically that companies source internally what they perform well, and outsource what others perform well (Argyres, 1996). Knowledge-based explanations of choice assume that efficient production necessitates specialised investments in physical and human assets, whereas company specific investments are the source of valuable knowledge and capabilities (Poppo and Zenger, 1998). Solutions are searched via the choice of internal versus external (Nickerson and Zenger, 2004). The degree of knowledge risk is hence an attribute to be considered when outsourcing (Schwarz et al., 2009). In fact, different writings in the literature emphasise the positive influence of outsourcing product development based on company internal capabilities from the knowledge viewpoint. (Afuah, 2001; Ahmadjian and Lincoln, 2001; Chen et al., 2009, 2011; Chesbrough et al., 2006; Cohen and Levinthal, 1990; Luca and Atuahene-Gima, 2007; Laursen and Salter, 2006; Rothaermel and Deeds, 2006; Zhang et al., 2009). As Mitchell and Parmigiani (2009) emphasised that knowledge enhancement not only can be the major incentive and the reason for a company to outsource, but knowledge can also be gained as being in collaboration with external companies further improves company knowledge and capabilities.

Knowledge is also in the core of strategic alliance decisions as sharing knowledge, including technology and capabilities have been seen as the main objectives of forming an alliance (Dyer and Nobeoka, 2000; Kale et al., 2000). Acquiring knowledge is assumed to be the goal of strategic alliances from the organisational learning perspective, each alliance member seeking to learn faster than the partner (Hamel, 1991). Nevertheless, Grant and Baden-Fuller (2004) argue that the primary advantage of alliances over both firms and markets is in the access rather than acquiring knowledge. Furthermore, knowledge transfer and resource sharing are sough in strategic acquisitions that are seen to often fall short of expectations (Schoenberg, 2001). Nevertheless the timeframe is a factor as the transfer of technological know-how is seen to be facilitated by communication, visits and meetings, and by the time elapsed since acquisition (Bresman et al., 1999).

Hence, it can be said that he most crucial resource of a company is knowledge, which can make the superior competitive advantage (Sveiby, 2001). The organisation adds value by transferring knowledge, involving external and internal resources (Allee, 2000), while KBT assumes that transferring knowledge to new people adds value to them, while also remaining with the owner of the knowledge (Sveiby, 2001). According to Grigoriou and Rothaermel (2016) external sourcing that leads to new knowledge trajectories might potentially be substituting for knowledge paths suggested by internal development, and the effectiveness depends on the properties of internal knowledge production. In the case of knowledge-based theory, it appears that applying the theory on product development sourcing decisions over the technology life-cycle stages is scarce in the previous literature.

\subsubsection{Resource-based theory}

Resource-based theory looks at the resources as the assets pointing how a combination of external and internal resources can build powerful competitiveness for a company, while the limitations of a company can be identified by the gap between its capabilities and 
external capabilities (Das and Teng, 2000; Madhok, 1997; McIvor, 2009). Building competitive strategies for the company based on internal competence and capabilities, and external circumstances has been emphasised, while resource-based theory emphasise how a company can be superior by utilising external capabilities (Nyberg et al., 2014; Proctor, 2014). In RBT, the resources are seen as 'processed by the firms' as many of them belong to specialised firms and are not mobilised or imitable (Das and Teng, 2000). RBT bases on six conditions of resource heterogeneity, rarity, imitability, sustainability, expose limit and imperfect resource mobility (Peteraf, 1993), all of which have uses in investigating companies and their suppliers. Similarly, different models are built based on RBT to analyse different industries' competitive advantage (e.g. Ghapanchi et al., 2014). Nevertheless, also critique has been presented as for example Bromiley and Rau (2016) criticise resource-based view for defining resources as strictly positive and not allowing for the possibility for negative or neutral impacts on performance, either directly or indirectly.

The resource-based view's perspective to outsourcing is relevant as superior performance is achieved in organisational activities relative to competitors, and the theory has uses in explaining why such activities would be performed internally. Outsourcing decisions are influenced by the ability of a company to sustain superior performance in relation to competitors (McIvor, 2009). Addressing outsourcing based on resources and capabilities means that core competencies are understood, those on which a company attempts to build future competitive advantage on (Bettis et al., 1992). Resource-based theory helps in understanding the core competencies. According to Grant (1996), the lack of resources can be addressed via outsourcing or strategic alliances. Some critique has also been presented, McIvor (2009) argues that the resource-based view alone cannot fully explain the complexities of outsourcing. Also, resource-based theory is not seen to adequately predict the level of outsourcing in all cases (Yap et al., 2016).

Strategic alliances, as well as acquisitions can help to access resources and capabilities (Lin et al., 2009). Alliances can in fact create combinations of resources that are unique and hence provide advantage (Lavie, 2006). The success of the alliance for intangible and tangible resources may however relate differently to the uncertainty situations, and situation of the competition for those resources (Dyer et al., 2004). There are also some indications that when considered from the resource-based perspective, certain managerial capabilities may benefit of strategic alliances (Lioukas et al. 2016). The same logic applies to strategic acquisitions as acquiring companies with relevant resources or capabilities can create an advantage (King et al. 2008). It has been widely accepted that executive turnover leads to lower post acquisition performance, yet Krug et al. (2014) challenge this and argue that the decision on the company executives is mostly a matter of context. This shows how the strategic acquisitions are complex and no simple truth exist. Product development sourcing decisions, however, appear not to have been discussed from the resource-based theory perspective over the technology life-cycle stages in the previous literature. 


\subsection{Synthesis}

As a synthesis of the literature findings, the sourcing strategies (outsourcing, strategic alliances and strategic company acquisition) are discussed under the structures of the three strategy building models (TCT, knowledge-based theory, resource-based theory). The essence of each strategy building model and the logic of the three models from the perspective of each sourcing strategy are illustrated (Table 1). Considering the sourcing strategies in this manner allows a level of simplification on the perspective of the strategy formulating theories.

Table 1 Sourcing strategies (outsourcing, strategic alliances and strategic company acquisition) through the lenses of the three strategy formulating theories (TCT, knowledge-based theory, and resource-based theory)

\begin{tabular}{|c|c|c|c|c|}
\hline & $\begin{array}{c}\text { Essence of the } \\
\text { theory }\end{array}$ & Outsourcing & Alliances & Acquisitions \\
\hline $\begin{array}{l}\text { Transaction } \\
\text { cost theory }\end{array}$ & $\begin{array}{l}\text { Lowest possible } \\
\text { production cost } \\
\text { and transaction } \\
\text { cost (Kogut, 1988; } \\
\text { Williamson, 1985) }\end{array}$ & $\begin{array}{l}\text { Maximise } \\
\text { production cost, } \\
\text { minimise } \\
\text { transaction cost } \\
\text { (Das and Teng, } \\
\text { 2000) while they } \\
\text { depend highly on } \\
\text { other factors } \\
\text { such as asset } \\
\text { specificity } \\
\text { (McIvor, 2009) }\end{array}$ & $\begin{array}{l}\text { Medium level } \\
\text { of transaction } \\
\text { and } \\
\text { production } \\
\text { costs (Das and } \\
\text { Teng, 2000; } \\
\text { Gulati, 1995) } \\
\text { In case of high } \\
\text { uncertainty } \\
\text { and asset } \\
\text { specificity } \\
\text { (Kogut, 1988) }\end{array}$ & $\begin{array}{l}\text { Production costs } \\
\text { are lower but } \\
\text { transaction costs } \\
\text { can be high in } \\
\text { accordance with } \\
\text { uncertainty, and } \\
\text { asset specificity } \\
\text { (Kogut, 1988) }\end{array}$ \\
\hline $\begin{array}{l}\text { Knowledge- } \\
\text { based theory }\end{array}$ & $\begin{array}{l}\text { Knowledge and } \\
\text { capabilities of a } \\
\text { company should } \\
\text { be maximised to } \\
\text { have sustainable } \\
\text { competitiveness } \\
\text { and best } \\
\text { performance } \\
\text { (Sveiby, 2001) }\end{array}$ & $\begin{array}{l}\text { Outsourcing can } \\
\text { increase } \\
\text { knowledge } \\
\text { capabilities of a } \\
\text { company (Afuah, } \\
\text { 2001; Cohen and } \\
\text { Levinthal, 1990; } \\
\text { Gupta and } \\
\text { Polonsky., 2014; } \\
\text { McGrath and } \\
\text { McMillan, 2000; } \\
\text { Rothaermel and } \\
\text { Deeds, 2006) } \\
\text { while } \\
\text { opportunism } \\
\text { should be seen } \\
\text { (Bhattacharya } \\
\text { et al., 2015; } \\
\text { Handley and } \\
\text { Angst, 2014) }\end{array}$ & $\begin{array}{l}\text { The critical } \\
\text { knowledge is } \\
\text { not inside the } \\
\text { company } \\
\text { completely or } \\
\text { partially, and } \\
\text { knowledge is } \\
\text { complex, and } \\
\text { while } \\
\text { developing it } \\
\text { internally is } \\
\text { time } \\
\text { consuming } \\
\text { and expensive } \\
\text { (George et al., } \\
\text { 2002; } \\
\text { Hagedoorn, } \\
\text { 1993; Patzelt } \\
\text { et al., 2008; } \\
\text { Rothaermel } \\
\text { and Deeds, } \\
\text { 2006; Wei } \\
\text { et al., 2000) }\end{array}$ & $\begin{array}{l}\text { Knowledge } \\
\text { acquisition can } \\
\text { be a known } \\
\text { reason for } \\
\text { strategic } \\
\text { company } \\
\text { acquisitions } \\
\text { (Ferriera et al., } \\
\text { 2014) }\end{array}$ \\
\hline
\end{tabular}


Table 1 Sourcing strategies (outsourcing, strategic alliances and strategic company acquisition) through the lenses of the three strategy formulating theories (TCT, knowledge-based theory, and resource-based theory) (continued)

\begin{tabular}{|c|c|c|c|c|}
\hline & $\begin{array}{c}\text { Essence of the } \\
\text { theory }\end{array}$ & Outsourcing & Alliances & Acquisitions \\
\hline $\begin{array}{l}\text { Resource- } \\
\text { based theory }\end{array}$ & $\begin{array}{l}\text { Adding value by } \\
\text { adding external } \\
\text { superior resources } \\
\text { (Das and Teng, } \\
\text { 2000; Madhok, } \\
\text { 1997) }\end{array}$ & $\begin{array}{l}\text { Outsourcing can } \\
\text { reinforce internal } \\
\text { capabilities and } \\
\text { competitive } \\
\text { advantage } \\
\text { (Coates and } \\
\text { McDermott, } \\
\text { 2002) }\end{array}$ & $\begin{array}{l}\text { Important } \\
\text { capabilities } \\
\text { are not inside } \\
\text { the company } \\
\text { and gaining } \\
\text { them via } \\
\text { internal } \\
\text { capabilities is } \\
\text { timely and } \\
\text { costly } \\
\text { (Madhok, } \\
\text { 1997) }\end{array}$ & $\begin{array}{l}\text { There is an } \\
\text { enormous } \\
\text { amount of } \\
\text { capabilities that } \\
\text { are needed, or the } \\
\text { market for } \\
\text { acquired } \\
\text { company is vast } \\
\text { (Eisenhardt and } \\
\text { Schoonhoven, } \\
\text { 1996). } \\
\text { Acquisition is a } \\
\text { beneficial } \\
\text { bargain to benefit } \\
\text { of the acquired } \\
\text { market in terms } \\
\text { of customer and } \\
\text { other assets like } \\
\text { brand name } \\
\text { (Oster, 1990; } \\
\text { Stettner and } \\
\text { Lavie, 2014; Yip, } \\
\text { 1982) }\end{array}$ \\
\hline
\end{tabular}

Considering the focus of product development activities over TLC stages can be beneficial to perceive the development emphasis at different stages. This information is required to consider suitable sourcing strategies for different situations. On the other hand, also considering the perspectives of the three strategy building models (TCT, KBT, and RBT) allows better understanding the different situations from the perspectives of transactions costs, knowledge and resources to make better, educated product development sourcing decisions. This type of approach may allow rough understanding of priorities for sourcing strategies over TLC stages in different situations. Figure 1 provides a synthesis where product development characteristics in different stages of TLC are illustrated in the upper part, and the sourcing strategies in accordance with the TLC stages and strategy building models in the lower part. 
Figure 1 Product development activities over TLC stages with the priority of each sourcing strategy based on the strategy formulating models (see online version for colours)

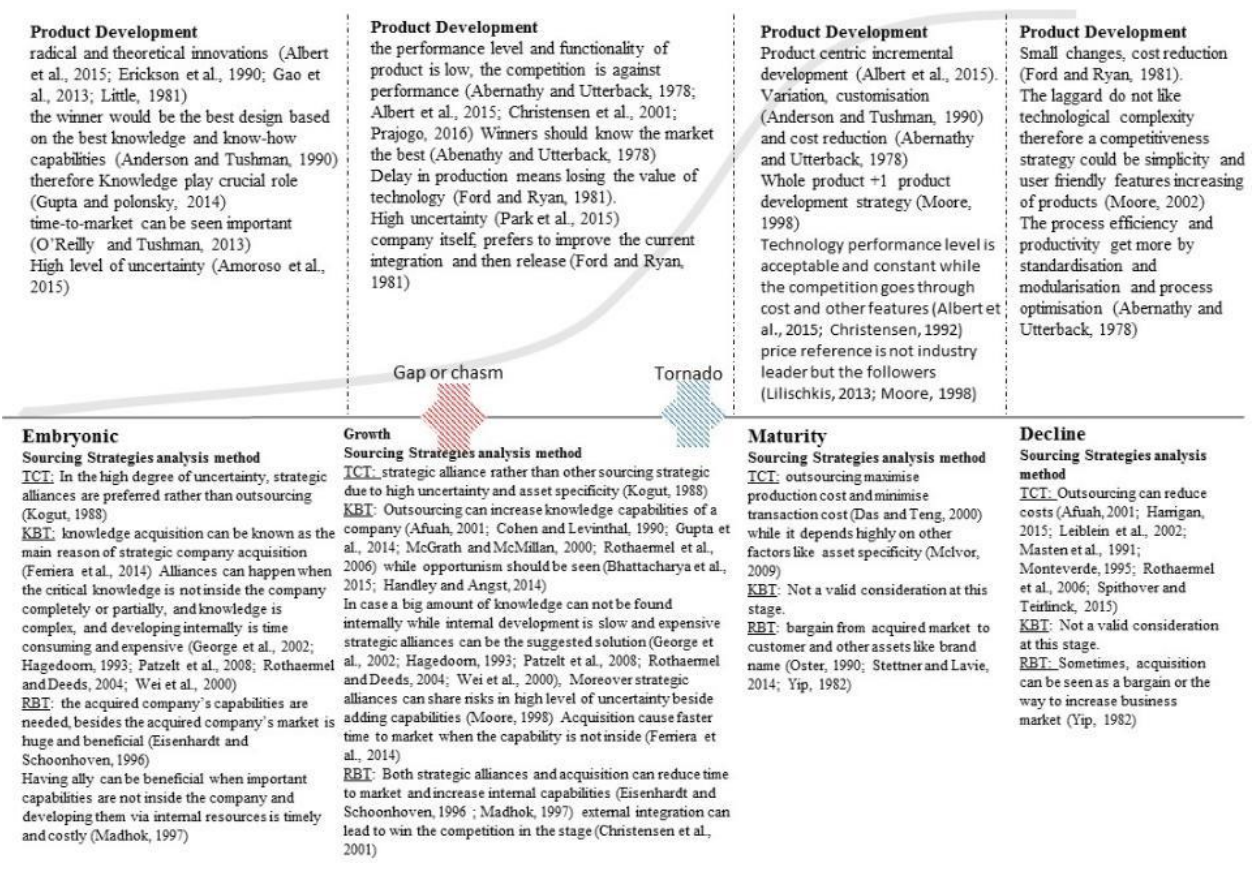

\section{Methodology}

The purpose of this study is to analyse product development sourcing strategies over technology life-cycle stages by acknowledging the technology maturity levels to find drivers for selecting suitable sourcing strategies for different situations. The study is based on an extensive review of literature and a study on the experiences of a well-known high-tech infrastructure provider. The empirical study focuses on product development sourcing over three technology generations covering information over almost three decades. The study is qualitative by nature and applies inductive reasoning in its logic. Qualitative nature of the study allows to explore the studied phenomenon (Ghauri and Grønhaug, 2005) in ways that might not be possible by utilising a quantitative approach. Also the sample to be utilised when using qualitative approach is discretionary to the researcher, yet the emphasis is on the quality of input material that must be adequate for the type of analysis and interpretations (Siggelkow, 2007).

In order to be able to explore product development sourcing strategies over technology life-cycle stages, the technology life-cycle related literature was first analysed carefully. In fact, technology life-cycle forms the platform for the entire study and hence TLC's and their characteristics are first considered. The three main sourcing strategies of outsourcing, strategic alliances, and acquisition were selected as those to be analysed as alternatives for internal sourcing. Internal product development sourcing meaning the situation when the company uses wholly in-house knowledge, personnel and assets (Cassiman and Veugelers, 2006). Hence, the literature on sourcing strategies is analysed. 
Three different strategy formulating models including TCT, knowledge-based theory and resource-based theory were selected to analyse the sourcing strategies from their distinctive perspectives and to support investigating sourcing strategies over a technology life-cycle stages. The relevant factors and the characteristics of each of these three strategy formulating models are analysed based on the literature. In addition, each of the three selected sourcing strategies (outsourcing, strategic alliances, and acquisition) is analysed from the viewpoint of the strategy defining models. The logic of each strategy formulating model is synthesised together with the perspective of each sourcing strategy. Finally based on the literature as a result of synthesis, product development activities are described over TLC together with sourcing strategies in accordance with TLC stages and the strategy formulating models. This way a rough picture of the priority of each sourcing strategy can be obtained over the TLC stages. The research framework of this study (Figure 2) is hence constituted of the described elements.

Figure 2 Research framework

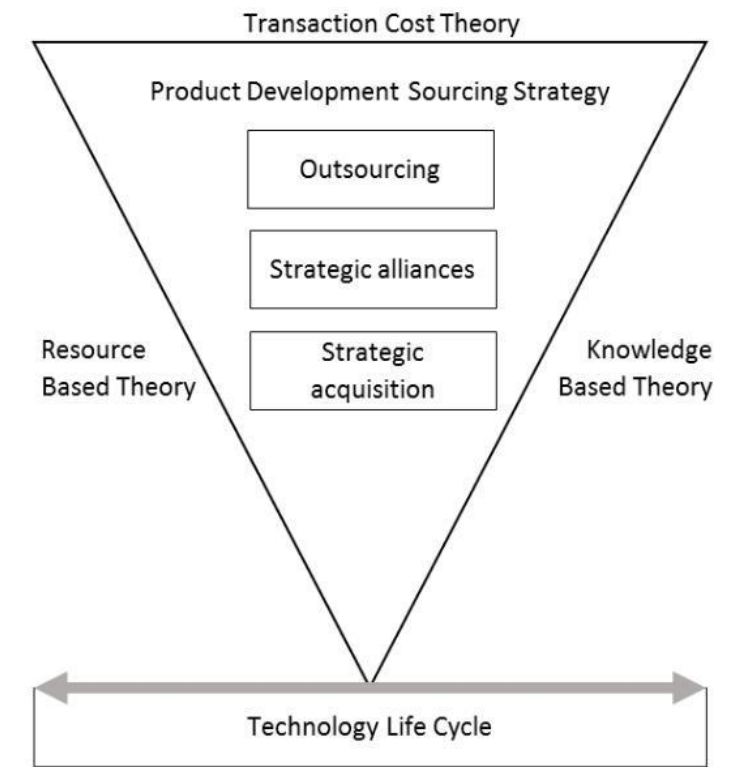

The empirical part of the study consists of analysing a high-tech infrastructure provider, their experiences, and their data on three technology generations (A, B and C). The case company was selected based on the opportunity to have an access to a company that is one of the world leaders in its business, and also based on the possibility to analyse three technology generations simultaneously. The well-known company operates in businessto-business markets providing high-tech products and equipment to a variety of customers. The company has a significant number of employees, operations in over 100 countries with significant revenue. The data for this study is collected qualitatively during nine semi-structured interviews (Merton et al., 1990). The interviewees consist of R\&D managers who have been working for the company over different technology generations. In addition, four group meetings with seven participants were held with high-level R\&D directors whom have been influential in strategic decisions and are aware of market and technology fluctuations in the industry. The interviews were 
recorded to enable thorough analyses, while the interview atmosphere was informal to gain more accurate data. Aside the semi-structured interviews the data sources included personal observations, and company confidential material. The variety of analysed material enabled triangulating and cross-verifying the findings (Yin, 2003) and also helped to ensure reliability of the research. Based on the empirical study a trend of sourcing strategies covering three technology generations is presented along a technology life-cycle stages. Conclusions were drawn based on analysing the interview material and reflecting the empirical findings against those of literature.

\section{Results}

The empirical part focuses on different sourcing strategies, including outsourcing, strategic alliances, and strategic company acquisitions during different technology generations (A, B and C) based on three strategy building models of TCT, resource-based theory and knowledge-based theory. Each of the discussed models builds their decisions on different motivations and is based on distinctive priorities. Hence, sometimes the models have similar aims, and the decisions, mostly those basing on resource considerations and knowledge considerations are supportive. Some apparent contrast between the strategy building models' justifications was also evident. Therefore, the company strategic decisions are brought forward and discussed, revealing the logic of the made decisions and their basis, linked to the relevant models.

Technology A is the first digital generation of the technology that made the systems significantly more efficient allowing far greater penetration levels than the analogue predecessor. Technology A allowed providing services that were not possible before, while the system capacity increased and the quality of the main benefit of the technology was improved. The technology generation A experienced introduction or embryonic phase from 1987 to 1991, when the main aim of product development was developing the best performance at the right time, so that the company could be part of industry standards. While a big part of knowledge capabilities did not exist within the company at the time, they had a strategic alliances with some other companies within the industry. Strategic alliance activities contained about $67 \%$ of the entire product development activities of generation A. The internal team which was collaborating in the strategic alliance consisted mostly of talented recent graduates who learned the knowledge quickly and helped the company to bypass the alliances by 1991 when the product entered the market The best just graduated electrical engineers were working in the development team to learn the new system, they were smart and their duty was to internalize the knowledge. After four years we left the consortium and became the toughest competitors of our former allies one of the R\&D director admits. At this point, the company started its own internalised product development. Therefore entering the strategic alliance with the aim of knowledge acquisition had been successful, and already in the growth phase of the technology the relevant knowledge was completely internalised. Besides, about $5 \%$ of activities were outsourced to professional companies that could handle those activities cheaper than the internal resources, based on the logic of TCT. The relevant knowledge relating to the outsourced activities was internally available and the internal resources had the capabilities of developing them further. Hence, due to not involving core competencies, internalisation of the outsourced activities would have not added any value. 
Subsequently, between 1991 and 1994 the technology A stayed in the chasm due to lack of integration with those external companies that were producing end-user devices. One of the R\&D directors represented: The technology was introducing a new exciting horizon for the end users, though the end-user devices were not ready. After the introduction of the first end-user device with the new functionality, the sales diagrams were boiling to the climax point like crazy. By 1994 when the first user devices came to the market with new features, the technology A went into tornado, suggesting that the company should produce products in the most efficient way besides keeping track of performance enhancements and cost reduction activities. In the previous stage the company had been able to acquire the knowledge capabilities mostly by the internal resources, therefore in the beginning of the growth phase the products were developed by internal resources. At this point, the trained internal resources were not only more productive but also developed products that were more efficient and customer friendly. One of the R\&D managers stated: Our own engineers were smarter and more familiar with the policy of the company, on the other hand they did not have language barriers and they were so collaborative, some of the results of the internal $R \& D$ team were mind blowing and not even comparable with the systems designed under the alliance condition. However, for some parts of product development activities, those that were considered as non-core competence, such as testing and prototyping, were outsourced. Those outsourced non-core activities, consisting of about $10 \%$ of the entire product development activities were known as more efficient than the alternatives. We needed to be as fast as the market, and did not have the time to attach new R\&D teams with new capabilities. There was no time for complexity and learning, and was not the right place for ambitious expansions, all the none-core activities were outsourced.

In 1995, the technology generation A got mature. The basic targets of product development at this stage were performance and feature improvement, which caused indirect cost reductions for both business customers and the end-users. As in the previous product development phase, only a part of activities were outsourced, mostly testing and prototyping which included about $10 \%$ of the entire product development activities. At this time, as the technology maturity had increased and product enhancements required further knowledge in company's core competence areas and technologies. Therefore, in order to acquire the needed knowledge, the company entered another strategic alliance with powerful partners. The company gained the required knowledge through the collaboration, not only resulting in internal knowledge enhancement but also increased technology products' efficiency.

As a consequence of the developments, the technology A got aged in 2010. Even though the technology had aged, it has been still been profitable to date and the company is still developing products based on this technology with an aim of further efficiency and cost reduction. Naturally, the knowledge is internally available, but using internal resources for a technology that is getting aged does not seem logical. Therefore, due to internal resources better being used in more strategic product development activities, those other than cost reduction for loyal customers resulting about $30 \%$ of the entire activities were being outsourced. We do not need the knowledge and we do not want to have a monster size product development factory that can be difficult to rule, so other can do the minor modifications and efficiency improvement development. At the time new technology generations already existed. While the crucial strategic sourcing decision at the stage was being a part of a strategic alliance, which was trying to integrate different technology generations into a single product meaning that a single product could provide 
multi technology generations' services for customers. More efficient, more user-friendly and easier to shift from one technology generation to the other by the end-user devices. The mature technology has its own few customers based on its application and its financial situation, therefore it has been crucial to provide hardware and software which support two or three technology generations at the same time, that is how we tried to produce such products under collaboration with allies another R\&D director admitted. Therefore, about 5\% of entire product development activities were realised in collaboration with allies. As a consequence, product development activities of generation A were outsourced partially in non-core competence areas such as testing and prototyping. Simultaneously in terms of knowledge acquisition, the company tried to internalise knowledge capabilities by being a part of strategic alliances, and in fact was successful through all the three stages: embryonic, growth and maturity. The current trend with this technology in question is that some customers in certain countries are ceasing services that are based on this technology during 2016-2021 The technology is cheaper to use and more reliable, although the capacity of service is low, lots of infrastructure spots which do not need wider capacities are still depending on the declining technology. Moreover, the end-user products are cheaper and totally more reliable, that is the reason for customers to have inertia of keeping the old technology products for a while.

Technology B was based on certain standards and came with applications that revolutionised the way the end-user devices could be used, simultaneously security and reliability of the technology were far better than the predecessor's. Technology generation B's embryonic phase started in 1995, concurrently with the generation A transferring from growth phase into maturity. In fact, it took about six years until 2001 before the first technology B based product entered the market. Technology generation B was developed almost completely internally. The case company had the knowledge within the company, and as the previous generation was yielding so well that the company had the possibility to maintain the resources and know-how within the organisation. The only part of product development that was taken care externally, was part of testing and prototyping. In those cases, the equipment and knowledge were not internal and were not seen to be needed because testing and prototyping were outside of the company's core competence. Therefore about $30 \%$ of product development activities were outsourced to provide the product technology to the market in larger scale in 2002.

In 2001, the initial first sales item of the technology B generation sold out. While until 2005 generation B sales did not touch growth requirements, because of two reasons: firstly the technology was not yet reliable and secondly there were no devices for the endusers that could utilise the new capabilities of the technology B. Although in 2006 when the end-user devices were introduced to the market and the technology became more reliable, tornado started and only within a year the technology moved into maturity phase. It was a bomb! one R\&D manager admits, The sales in the first six month of 2006 was three times more than the entire sales estimated for the technology. Therefore, in order to improve performance, the case company acquired an established company who had strong capabilities in generation B. This was to add to the company's resources and acquire necessary knowledge capabilities. Moreover, they used smart strategic products that utilised the acquired knowledge and resources. This was integrating the previous and current technology generations (A and B) to not only satisfy conservative customers but also new adopters. Additionally, acquiring a big established company caused adding a new market to the portfolio with a big portion of business that could bring a lot of 
monetary value to the company. Therefore the acquisition strategy was not only explained by knowledge-based theory analysis, which was the main reason for the acquisition, but also by resource-based and TCT analysis. At this stage, the testing and prototyping part of product development remained to be outsourced as for the previous generation.

Subsequently, technology generation B got mature in 2006, and product development activities continued with the target of cost reduction both directly and indirectly. This was by improving efficiency features and optimising the process to install bases as much as possible in order to maintain customer loyalty. At this point, generation B was selling so much that the company was excited to find as much resources as possible to develop more products. Therefore, the company bought another established company with a large amount of capable resources besides an enormous business share. The case company was now not only enjoying the new capabilities but also a lot of money was coming in. The basic motivation for the acquisition was adding resources according to resource-based theory, while choosing acquisition strategy was also rather well in line with the requirements of TCT. Although the knowledge base of the company was in edge point of the technology and the company did not need any sourcing strategy decisions based on knowledge acquisitions. Our internal engineers were working perfectly, though the new acquired company had huge capabilities besides the great market expansion opportunity. Therefore internal engineers were supervising the process of merging new $R \& D$ teams into the company and familiarising them with our organisational cultures one of the R\&D managers explained. Additionally, after the acquisition of the established company, the case company was responsible for a big portion of the market, customer demands required a lot product development activities and they decided to enter a strategic alliance in product development to utilise partners' resources in some product development activities.

Acquiring two well established companies with high competences in generation B technology besides collaborating in the form of strategic alliances resulted in the company having high knowledge and capabilities in generation B development. Additionally, from the perspective of TCT they were capable of financing various advanced product development activities. Therefore, in the middle of product development activities for generation B the case company developed generation C concept definition and introduced it. We were working greatly, we had knowledge, funds and resources, all the high quality $R \& D$ activates lead into the new concept with was much better than the previous generation although it was just found by generation $B$ related lab engineers. While the new developed technology generation and big portion of business capabilities caused the company to ambitiously acquire another established company with high competences. The acquisition added yet another knowledgeable product development resource foundation to the company which caused faster and more efficient technology development. Now the company was quicker than competitors in establishing standards and producing real products for the market as they had a huge potential base of know-how and capabilities.

Technology $\mathrm{C}$ was based on even more stringent standards and came with ever new possibilities for the way the end-user devices could be used. Finally in 2011 the first technology $\mathrm{C}$ based product entered the market, although product development process was quick and efficient the first introduced product was expensive, slow and not reliable, so the technology generation $\mathrm{C}$ stood in the chasm phase for a couple of years. The case company made another strategic decision, and acquired a competitor with a big amount 
of capability and resources in generation $\mathrm{C}$, which contained about $10 \%$ of the entire product development activities. The acquisition decision was made based on knowledgebased theory to reinforce internal capabilities. Additionally at the time, the company was simultaneously working on three different generations' product development. Even though they acquired additional resources and capable people, the acquired companies had their own business market to be met as well, therefore resource-based theory analysis requirements were fulfilled. The tornado started as a result of introducing more reliable products in 2013. The products had more reasonable prices and linked to more integrated end-user devices. The technology generation $\mathrm{C}$ was in tornado until 2014 until the entire generation went into maturity phase. The product development activities were continued by sharing resources in a strategic alliance to produce cheaper and more efficient products with better functionalities. This was based on the TCT perspective. At this stage the almost constant portion of outsourced product development of non-core activities contained about $3 \%$ of whole product development activities. Sourcing decisions through the described technology generations A, B, and C could be described by the three strategy formulating models, while various internal and external factors were influencing the made decisions. Next technology generation $\mathrm{D}$ is already under development, but was excluded as out of the scope of this study due to high confidentiality and the current stage of development. The focus of generation D development is slightly different to its predecessors. We are still trying to find out what the next generation concept can be, although we are working hard with lots of research institutions under high pressure to be part of standardisation process of the next generation as we have been for the past generations a R\&D director states.

As a conclusion to the above described, Figure 3 illustrates the trend of sourcing strategies as a part of a technology life-cycle. In the case of technology generation A, the company did not have a big part of critical knowledge internally, therefore based on KBT analysis they entered an alliance to enhance internal knowledge. Opposed to generation $\mathrm{A}$, most of the product development activities had been preferred to be done internally in generation $\mathrm{B}$ and $\mathrm{C}$, during their embryonic phases, due to the knowledge capabilities being internally available. Only a small portion of non-core activities were outsourced in the case of generations B and $\mathrm{C}$. The case company did utilise acquisition in the case of generation $\mathrm{C}$ to expand company business and to add resources.

In the growth phase of technology generation $\mathrm{A}$, internalised knowledge capabilities allocated almost all of the company's product development activities, except some noncore parts. Technology generation $\mathrm{B}$ and $\mathrm{C}$ in addition to outsourcing, had some strategic acquisition in their portfolio which were under resource-based and knowledge-based analysis methods. While the amount of product development activities under collaboration with strategic allies with regards the technology generation $\mathrm{C}$ seems considerable (10\%), that can be explained in accordance with the company improvement in the industry and aim of expanding the business and resources.

Subsequently, in maturity phase the company aimed to externalise product development further, while for technology B the sourcing strategies had a smaller integration level (strategic alliances and acquisition) as while the percentages had growth as the flexibility improved and uncertainty became less. The continuation of the mentioned trend can be found in the decline phase as well, while only $65 \%$ of the whole product development activities are internalised. 
Figure 3 Trend of sourcing strategies for technology generations A, B and C along a technology life-cycle (see online version for colours)

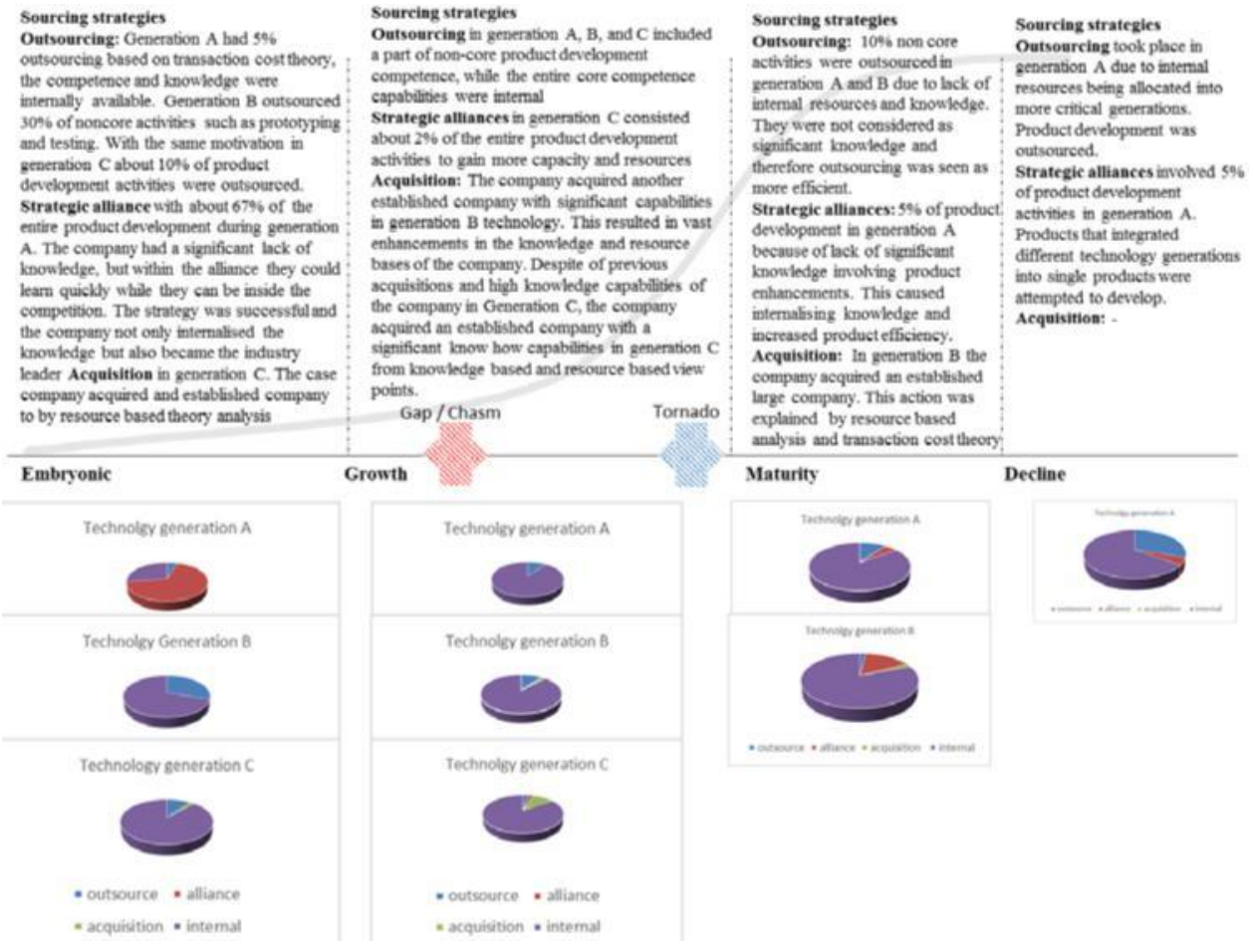

\section{Discussion}

The empirical part focuses on different sourcing strategies, including outsourcing, strategic alliances, and strategic company acquisitions during different technology generations (A, B and C) and presents the developments based on three strategy building models of TCT, RBT and KBT. The results emphasise the trend of the importance of knowledge against the importance of costs, which affects both, mapping product development activities and selecting product development sourcing strategies. This is in line with the TCT's emphasis on cost efficiency, therefore in the beginning of technology life-cycle when high uncertainty is present and asset specificity prevails, internalising could be seen as the most efficient strategy (Kogut, 1988). However as knowledge is more important than the cost in the beginning of the life-cycle, especially when the knowledge is not internally available, a company can utilise external sources based on knowledge-based theory and resource-based theory. This is in line with the literature (George et al., 2002; Hagerdoorn, 1993; Patzelt et al., 2008; Rothaermel and Deeds, 2006; Wei et al., 2000). According to the results of this study strategic alliance is a good sourcing strategy in the absence of internal capabilities for gaining knowledge in the beginning of a technology life-cycle. This seemed to be also the case for the technology generation A where $67 \%$ of the entire product development activities were done in partnering with allies. In other words, strategic alliance is a good strategy for gaining 
knowledge in the beginning, while later outsourcing can be better from the cost efficiency perspective. For this reason, later on during the technology decline phase when the company was trying to reduce costs, outsourcing was seen as a better approach, which is also in line with the TCT. Based on TCT, outsourcing can reduce costs, a fact that is well discussed also in the previous literature (Afuah, 2001; Harrigan, 2014; Leiblein and Miller, 2003; Masten et al., 1991; Monteverde, 1995; Rothaermel and Deeds, 2006; Spithoven and Teirlinck, 2015). The company wanted to keep the technology generation A in the market during the decline phase as it still resulted in profitable products. Outsourcing and using external cheaper resources at this stage can be supported by the TCT. Additionally, as the internal resources can be allocated in more strategic technology generations' product development, outsourcing at this stage can meet resource based theory's requirements as well. Hence, the product development knowledge was internally available and outsourcing could not be supported by the knowledge-based theory.

The case company had almost always a constant percentage of product development that was outsourced during the technology generations. The outsourced portion included non-core and non-strategic product development activities. This is a very traditional way of outsourcing and is in line with the previous literature (Moore, 1998, Rita and Krapfel, 2015). Outsourcing non-core, non-strategic product development activities is in line with RBT, TCT, and KBT. In line with resource-based theory for the reason that there is no need to add on company internal resources; with TCT as it is cheaper to outsource; and knowledge-based theory as all the knowledge is not needed internally. In the case company, the non-core, non-strategic activities included prototyping and testing activities.

In some ways this study presents a legacy of a powerful company from the beginning of its emergence to the current date. The company's acquisition strategy started at the time the company became the industry leader and the company had been best seller for years. The company was gaining the business and resources other than knowledge, while the acquisition of small start-ups would make a different story. Moreover, acquisition is basically a merger strategy where company size, business and resources other than knowledge are acquired. This is in line with the studies that appreciate acquisition for adding value in technological competence section (e.g. Chatterji, 1996) and others that found business extension benefits of strategic acquisition (e.g. Harrison et al., 1991). Acquisitions in the case company took place due to financial success of the acquired companies and could be considered as bargains, which is line with TCT. The case company also extended their resources, particularly in technology generations $\mathrm{B}$ and $\mathrm{C}$, which is in line with resource-based theory. However, as they had the knowledge internally before the acquisitions, knowledge acquisitions could not be seen as one of the targets and the acquisition decisions were not made based on the knowledge-based theory.

Product development sourcing strategies are typically discussed in the literature from the product viewpoint (Moore, 1998, Rita and Krapfel, 2015), and the viewpoint of different theories (e.g., Rothaermel and Deeds, 2006; Spithoven and Teirlinck, 2015). The way sourcing strategies are viewed as a part of technology life-cycle stages in this study, based on technology maturity levels is new to the literature. The novelty of this study is discussing sourcing strategies based on technology maturity over technology lifecycles. 


\section{Conclusions}

This study focuses on product development sourcing strategies based on technology maturity levels over technology life-cycle stages. Three selected external sourcing strategies, based on the level of company integration are utilised to map sourcing strategies over technology a life-cycle, including outsourcing, strategic acquisitions, and strategic alliances. Three strategy formulating models are employed to find drivers for selecting suitable sourcing strategies. These models include TCT, knowledge-based theory, and resource-based theory. The study is realised as a combination of a thorough literature review and analysing a high-tech infrastructure provider and their data on three technology generations (A, B and C).

The unique contribution of this paper entails analysing sourcing strategies from the perspective of three strategy formulating models over a technology life-cycle stages. This study contributes by creating a framework where product development activities emphasis and sourcing strategies' focus is presented over TLC by indicating the priority of each strategy formulating model in different situations. This study also provides contribution by analysing the sourcing strategies of an important player in the high-tech infrastructure business simultaneously over three technology generations and presents the employed sourcing strategies over a technology life-cycle, while also discussing motivations behind the decisions.

It appears that product development sourcing strategies can be discussed according to technology life-cycle stages based on different factors, including the characteristics of the stage, characteristics of the product development activities, and factors and drivers of each product development sourcing strategy. It seems that product development sourcing strategies can be discussed according to technology life-cycle stages under factors that are drawn by strategy formulating theories. In the beginning of the technology life-cycle, knowledge capabilities play a crucial role in sourcing decisions for technology product development, while later on when technologies become more mature cost reduction becomes more important influencing the selected sourcing strategies.

Three different strategy formulating models were discussed over different stages of a technology life-cycle. Each model has a focus based on certain factors and requirements influencing the perspective over the stages of the technology life-cycle. One or two of the models can be seen bolder than the others, therefore the factors and requirements could be seen as the foundation of decision making when choosing product development sourcing strategies. For instance, in the embryonic stage, the knowledge acquisition and knowledge capabilities are considered as the enablers for the company to compete. Hence, knowledge-based theory and its requirements play a pivotal role in making decisions during the embryonic stage, while later on during technology maturity the importance of cost efficiency becomes more significant. Therefore, transaction cost and resource based theories' requirements and factors should be considered for making better decisions later on.

The theoretical implications of this study include discussing sourcing strategies over a technology life cycle based on the maturity levels, providing new contribution taking the fact that product development sourcing strategies are typically discussed from the product viewpoint (Moore, 1998, Rita and Krapfel, 2015), and the viewpoint of single theories (e.g., Rothaermel and Deeds, 2006; Spithoven and Teirlinck, 2015). Scientific discussion can benefit of TLC considerations when discussing sourcing strategies. Hence, this study also provides new contribution by including the perspective of three strategy formulating 
models simultaneously and tackling the lack of diversity in the analysis as named as a shortcoming of many studies by Sucky and Durst (2013). Including multiple perspectives can prove beneficial for procurement management discussion. Aside of including the TLC consideration to discussing sourcing strategies, this study also provides analysis of three technology generations simultaneously providing a rather novel contribution to the sourcing strategy related body of knowledge, potentially providing beneficial insights.

The managerial implications of this study encompass firstly the fact that decision making for product development strategies is seen from a new perspective over technology life-cycle stages, which may provide insights to the big picture. Managers can see technology life-cycles not only from the market viewpoint, but also from the perspective of company's products. Companies can map all of their products in a single picture to see how the products position along the stages of the technology life-cycle. This enables analysing the next steps from the perspective of product development activities. Moreover, by mapping all products, companies can view all the partners and the related history along the technology life-cycles of their products in addition to the history of their sourcing strategies that have been utilised together with their corresponding results. Additionally, this study proposes three different strategy building models for investigating the factors and requirements relevant to each life-cycle stage, and describes the prioritisation principles for these stages. Therefore, companies' decision makers might be less likely to be trapped in a single model's requirements and can view the matters from different angles.

Limitations of this study include analysing the product development sourcing strategies based on technology maturity levels during technology life-cycle stages in a single company. Hence, even though we tried to have as homogenous conditions as possible for studying different technology generations to build a concrete model, the model should be tested, and further developed by utilising other companies' data. The limitations also include the possibility of technological maturity potentially having some company specifics in interpretations. This paper merely uses the logic and the essence of the strategy formulating theories and applies it on product development sourcing over a TLC and does not utilise the formulas and quantitative procedure. Also, the three strategy building models that are discussed in this study, support different aspects of decision making process, however, other models may help to improve the decision accuracy. Therefore, further studies could address these limitations and take the found idea further by involving other industries and technologies, and potentially apply additional strategy building models to the presented concept.

\section{References}

Abernathy, W.J. and Utterback, J.M. (1978) 'Patterns of industrial innovation', Technology Review, Vol. 64, No. 7, pp.254-228.

Achilladelis, B. (1993) 'The dynamics of technological innovation: the sector of antibacterial medicines', Research Policy, Vol. 22, No. 4, pp.279-308.

Achilladelis, B., Schwarzkopf, A. and Cines, M. (1990) 'The dynamics of technological innovation: the case of the chemical industry', Research Policy, Vol. 19, No. 1, pp.1-34.

Afuah, A. (2001) 'Dynamic boundaries of the firm: are firms better off being vertically integrated in the face of a technological change?', Academy of Management Journal, Vol. 44, No. 6, pp.1211-1228. 
Ahmadjian, C.L. and Lincoln, J.R. (2001) 'Keiretsu, governance, and learning: case studies in change from the Japanese automotive industry', Organization Science, Vol. 12, No. 6, pp.683-701.

Ahmed, R.R., Sattar, I., Khoso, I. and Parmar, V. (2014) 'New product development: strategy \& implementation mechanism based on primary \& secondary data research in pharmaceutical industry', International Journal of Management, IT and Engineering, Vol. 4, No. 5, pp.152176.

Albert, T., Moehrle, M.G. and Meyer, S. (2015) 'Technology maturity assessment based on blog analysis', Technological Forecasting and Social Change, March, Vol. 92, pp.196-209.

Allee, V. (2000) 'Reconfiguring the value network', Journal of Business Strategy, Vol. 21, No. 4, pp.36-39.

Amit, R. and Schoemaker, P.J. (1993) 'Strategic assets and organizational rent', Strategic Management, Vol. 14, No. 1, pp.33-46.

Amoroso, S., Moncada-Paterno-Castello, P. and Vezzani, A. (2015) R\&D Profitability: The Role of Risk and Knightian Uncertainty, IPTS Working Papers on Corporate R\&D and Innovation, No. 01/2015.

Anderson, P. and Tushman, M.L. (1990) 'Technological discontinuities and dominant designs: a cyclical model of technological change', Administrative Science Quarterly, Vol. 35, No. 4, pp.604-633.

Argyres, N. (1996) 'Evidence on the role of firm capabilities in vertical integration decisions', Strategic Management Journal, Vol. 17, No. 2, pp.129-150.

Asthana, P. (1995) 'Jumping the technology S-curve', Spectrum, IEEE, Vol. 32, No. 6, pp.49-54.

Barragan, S., Cappellino, C., Dempsey, N. and Rothenberg, S. (2003) 'A framework for sourcing product development services’, Supply Chain Management: An International Journal, Vol. 8, No. 3, pp.271-280.

Bettis, R.A. and Hitt, M.A. (1995) 'The new competitive landscape', Strategic Management Journal, Vol. 16, No. S1, pp.7-19.

Bettis, R.A., Bradley, S.P. and Hamel, G. (1992) 'Outsourcing and industrial decline', The Executive, Vol. 6, No. 1, pp.7-22.

Betz, F. (2011) Managing Technological Innovation: Competitive Advantage from Change, 3rd ed., Wiley \& Sons, Hoboken, NJ.

Bhattacharya, A., Singh, P.J. and Nand, A.A. (2015) 'Antecedents of buyer opportunistic behaviour in outsourcing relationships', International Journal of Production Economics, August, Vol. 166, pp.258-268.

Bresman, H., Birkinshaw, J. and Nobel, R. (1999) 'Knowledge Transfer in International Acquisitions', Journal of International Business Studies, Vol. 30, No. 3, pp. 439-462.

Bromiley, P. and Rau, D. (2016) 'Missing the point of the practice-based view', Strategic Organization, Vol. 14, No. 3, pp. 260-269.

Brouthers, K.D., Nakos, G. and Dimitratos, P. (2014) 'SME entrepreneurial orientation, international performance, and the moderating role of strategic alliances', Entrepreneurship Theory and Practice, Vol. 39, No.5, pp.1161-1187.

Brunswicker, S. and Vanhaverbeke, W. (2014) 'Open innovation in small and medium-sized enterprises (SMEs): external knowledge sourcing strategies and internal organizational facilitators', Journal of Small Business Management, Vol. 53, No. 4, pp.1241-1263.

Buvik, A. and Halskau, Ø. (2016) 'Contract complexity and contract administration costs in small supplier alliances in the Norwegian offshore market', International Journal of Procurement Management, Vol. 9, No. 1, pp.1-14.

Calvo-Mora, A., Navarro-García, A. and Periañez-Cristobal, R. (2015) 'Project to improve knowledge management and key business results through the EFQM excellence model', International Journal of Project Management, Vol. 33, No. 18, pp.1638-1651. 
Capron, L. and Mitchell, W. (2013) Build, Borrow, or Buy: Solving the Growth Dilemma, Harvard Business Press, Boston, MA.

Cassiman, B. and Veugelers, R. (2000) External Technology Sources: Embodied or Disembodied Technology Acquisition, Economics and Business Working Paper, University Pompeu Fabra, No. 444.

Cassiman, B. and Veugelers, R. (2006) 'In search of complementarity in innovation strategy: Internal R\&D and external knowledge acquisition', Management Science, Vol. 52, No. 1, pp.68-82.

Chatterji, D. (1996) 'Accessing external sources of technology', Research Technology Management, Vol. 39, No. 2, pp.48-56.

Chen, J., Chen, Y. and Vanhaverbeke, W. (2011) 'The influence of scope, depth, and orientation of external technology sources on the innovative performance of Chinese firms', Technovation, Vol. 31, No. 8, pp.362-373.

Chen, Y., Lin, M.J. and Chang, C. (2009) 'The positive effects of relationship learning and absorptive capacity on innovation performance and competitive advantage in industrial markets', Industrial Marketing Management, Vol. 38, No. 2, pp.152-158.

Chesbrough, H., Vanhaverbeke, W. and West, J. (2006) Open Innovation: Researching A New Paradigm, Oxford University Press, Oxford, UK.

Chiesa, V. and Manzini, R. (1998) 'Organizing for technological collaborations: a managerial perspective', $R \& D$ Management, Vol. 28, No. 3, pp.199-212.

Christensen, C.M. (1992) 'Exploring the limits of the technology S- curve. Part I: component technologies', Production and Operations Management, Vol. 1, No. 4, pp.334-357.

Christensen, C.M., Raynor, M. and Verlinden, M. (2001) 'Skate to where the money will be', Harvard Business Review, Vol. 79, No. 10, pp.72-83.

Clark, K.B. and Fujimoto, T. (1991) Product Development Performance: Strategy, Organization, and Management in the World Auto Industry, Harvard Business Press, Boston, MA.

Clark, K.B. and Fujimoto, T. (1992) Product Development Performance, Harvard Business School Press, Boston, MA.

Coase, R.H. (2007) 'The nature of the firm', Economica, Vol. 4, No. 16, pp.386-405.

Cohen, W.M. and Levinthal, D.A. (1990) 'Absorptive capacity: a new perspective on learning and innovation', Administrative Science Quarterly, Vol. 35, No. 1, pp.128-152.

Collet, F. and Philippe, D. (2014) 'From hot cakes to cold feet: a contingent perspective on the relationship between market uncertainty and status homophily in the formation of alliances', Journal of Management Studies, Vol. 51, No. 3, pp.406-432.

Das, T.K. and Teng, B. (2000) 'Instabilities of strategic alliances: an internal tensions perspective', Organization Science, Vol. 11, No. 1, pp.77-101.

Dickson, P.H. and Weaver, K.M. (1997) 'Environmental determinants and individual-level moderators of alliance use', Academy of Management Journal, Vol. 40, No. 2, pp.404-425.

Drucker, P.F. (1978) The Age of Discontinuity, Harper, New York, NY.

Dyer, J.H. and Nobeoka, K. (2000) 'Creating and managing a high performance knowledge-sharing network: the Toyota case', Strategic Management Journal, Vol. 21, No. 3, pp.345-367.

Dyer, J.H., Kale, P. and Singh, H. (2004) 'When to ally \& when to acquire', Harvard Business Review, Vol. 82, Nos. 7-8, pp.108-115.

Eltantawy, R., Giunipero, L. and Handfield, R. (2014) 'Strategic sourcing management's mindset: strategic sourcing orientation and its implications', International Journal of Physical Distribution \& Logistics Management, Vol. 44, No. 10, pp.768-795.

Erickson, T.J., Magee, J.F., Roussel, P.A. and Saad, K.N. (1990) 'Managing technology as a business strategy', MIT Sloan Management Review, Vol. 31, No. 3, p.73.

Ernst, H. (1997) 'The use of patent data for technological forecasting: the diffusion of CNCtechnology in the machine tool industry', Small Business Economics, Vol. 9, No. 4, pp.361381. 
Fenech, J.P. and Tellis, G.J. (2016) 'The dive and disruption of successful current products: measures, global patterns, and predictive model', Journal of Product Innovation Management, Vol. 33, No. 1, pp.53-68.

Ferreira, M.P., Santos, J.C., de Almeida, M.I.R. and Reis, N.R. (2014) 'Mergers \& acquisitions research: a bibliometric study of top strategy and international business journals, 1980-2010', Journal of Business Research, Vol. 67, No. 12, pp.2550-2558.

Fisher, J. and Pry, R. (1971) 'A simple substitution model of technological change', Technological Forecasting and Social Change, Vol. 3, No. 1, pp.75-88.

Fleming, L. (2001) 'Recombinant uncertainty in technological search', Management Science, Vol. 47, No. 1, pp.117-132.

Ford, D. and Ryan, C. (1981) 'Taking technology to market', Harvard Business Review, Vol. 59, No. 2, pp.117-126.

Galanter, M. (1981) 'Justice in many rooms: courts, private ordering, and indigenous law', The Journal of Legal Pluralism and Unofficial Law, Vol. 13, No. 19, pp.1-47.

Gao, L., Porter, A.L., Wang, J., Fang, S., Zhang, X., Ma, T., Wang, W. and Huang, L. (2013) 'Technology life-cycle analysis method based on patent documents', Technological Forecasting and Social Change, Vol. 80, No. 3, pp.398-407.

George, G., Zahra, S.A. and Wood, D.R. (2002) 'The effects of business-university alliances on innovative output and financial performance: a study of publicly traded biotechnology companies', Journal of Business Venturing, Vol. 17, No. 6, pp.577-609.

Ghapanchi, A.H., Wohlin, C. and Aurum, A. (2014) 'Resources contributing to gaining competitive advantage for open source software projects: An application of resource-based theory', International Journal of Project Management, Vol. 32, No. 1, pp.139-152.

Ghauri, P. and Grønhaug, K. (2005) Research Methods in Business Studies, 3rd ed., Prentice Hall, Harlow, Essex.

Ghoshal, S. and Moran, P. (1996) 'Bad for practice: a critique of the transaction cost theory', Academy of Management Review, Vol. 21, No. 1, pp.13-47.

Gilsing, V., Cloodt, M. and Roijakkers, N. (2015) 'From birth through transition to maturation: the evolution of technology -based alliance networks', Journal of Product Innovation Management, Vol. 33, No. 2, pp.181-200.

Grant, R.M. (1996) 'Toward a knowledge-based theory of the firm', Strategic Management Journal, Vol. 17, No. S2, pp.109-122.

Grant, R.M. and Baden-Fuller, C. (2004) 'A knowledge accessing theory of strategic alliances', Journal of Management Studies, Vol. 41, No. 1, pp.61-84.

Grigoriou K. and Rothaermel, F.T. (2016) 'Organizing for knowledge generation: internal knowledge networks and the contingent effect of external knowledge sourcing', Strategic Management Journal, EarlyView, DOI: 10.1002/smj.2489.

Gulati, R. (1995) 'Does familiarity breed trust? The implications of repeated ties for contractual choice in alliances', Academy of Management Journal, Vol. 38, No. 1, pp.85-112.

Gupta, S. and Polonsky, M. (2014) 'Inter-firm learning and knowledge-sharing in multinational networks: an outsourced organization's perspective', Journal of Business Research, Vol. 67, No. 4, pp.615-622.

Hagerdoorn, J. (1993) 'Understanding the rationale of strategic technology partnering: interorganizational modes of cooperation and sectoral diferences', Strategic Management Journal, Vol. 14, No. 5, pp.371-386.

Hamel, G. (1991) 'Competition for competence and inter-partner learning within international strategic alliances', Strategic Management Journal, July, Vol. 12, pp.83-103.

Hamel, G. and Prahalad, C. (1994) Competing for the Future, 1994, Harvard Business School Press, Boston, USA. 
Handley, S.M. and Angst, C.M. (2014) 'The impact of culture on the relationship between governance and opportunism in outsourcing relationships', Strategic Management Journal, Vol. 36, No. 9, pp.1412-1434.

Harrigan, K.R. (2015) Strategic Alliances as Agents of Competitive Change, Collaborative Strategy a Guide to Strategic Alliances, Elgar Book Series, Cheltenham.

Harrison, J.S., Hitt, M.A., Hoskisson, R.E. and Ireland, R.D. (1991) 'Synergies and postacquisition performance: differences versus similarities in resource allocations', Journal of Management, Vol. 17, No. 1, pp.173-190.

Haupt, R., Kloyer, M. and Lange, M. (2007), 'Patent indicators for the technology life-cycle development', Research Policy, Vol. 36, No. 3, pp.387-398.

Heide, J.B. and Weiss, A.M. (1995) 'Vendor consideration and switching behavior for buyers in high-technology markets', The Journal of Marketing, Vol. 59, No.3, pp.30-43.

Hennart, J. (1988) 'A transaction costs theory of equity joint ventures', Strategic Management Journal, Vol. 9, No. 4, pp.361-374.

Hennart, J. and Reddy, S. (1997), 'The choice between mergers/acquisitions and joint ventures: the case of Japanese investors in the United States', Strategic Management Journal, Vol. 18, No. 1, pp.1-12.

Hesping, F.H. and Schiele, H. (2016) 'Sourcing tactics to achieve cost savings: developing a formative method of measurement', International Journal of Procurement Management, Vol. 9, No. 4, pp.473-504.

Holloway, I., Lee, H.S. and Shen, T. (2016) 'Private equity firm heterogeneity and cross-border acquisitions', International Review of Economics \& Finance, July, Vol. 44, pp.118-141.

Jacobides, M.G. and Billinger, S. (2006) 'Designing the boundaries of the firm: from 'make, buy, or ally' to the dynamic benefits of vertical architecture', Organization Science, Vol. 17, No. 2, pp.249-261.

Kale, P., Singh, H. and Perlmutter, H. (2000) 'Learning and protection of proprietary assets in strategic alliances: building relational capital', Strategic Management Journal, Vol. 21, No. 3, pp.217-237.

Khalil, T.M. (2000) Management of Technology: The Key to Competitiveness and Wealth Creation, McGraw-Hill Science, Engineering \& Mathematics, Boston, MA.

King, D.R., Slotegraaf, R.J. and Kesner, I. (2008) 'Performance implications of firm resource interactions in the acquisition of R\&D-intensive firms', Organization Science, Vol. 19, No. 2, pp.327-340.

Kistruck, G.M., Morris, S.S., Webb, J.W., Stevens, C.E. (2016) 'The importance of client heterogeneity in predicting make-or-buy decisions', Journal of Operations Management, Vols. 33-34, pp.97-110.

Kogut, B. (1988) 'Joint ventures: theoretical and empirical perspectives', Strategic Management Journal, Vol. 9, No. 4, pp.319-332.

Kotabe, M. (1992) Global Sourcing Strategy: $R \& D$, Manufacturing, and Marketing Interfaces, Praeger Pub Text, New York.

Kotabe, M. and Helsen, K. (1998) Global Marketing Management, 2nd ed., Wiley and Sons, New York, NY.

Kozlenkova, I.V., Samaha, S.A. and Palmatier, R.W. (2014) 'Resource-based theory in marketing', Journal of the Academy of Marketing Science, Vol. 42, No. 1, pp.1-21.

Krug, J.A., Wright, P. and Kroll, M.J. (2014) 'Top management turnover following mergers and acquisitions: solid research to date but still much to be learned', Academy of Management, Vol. 28, No. 2, pp.147-163.

Laursen, K. and Salter, A. (2006) 'Open for innovation: the role of openness in explaining innovation performance among UK manufacturing firms', Strategic Management Journal, Vol. 27, No. 2, pp.131-150. 
Lavie, D. (2006) 'The competitive advantage of interconnected firms: an extension of the resourcebased view', Academy of Management Review, Vol. 31, No. 3, pp.638-658.

Lawson, B., Krause, D. and Potter, A. (2014) 'Improving supplier new product development performance: the role of supplier development', Journal of Product Innovation Management, Vol. 32, No. 5, pp.777-792.

Lee, T. and Nakicenovic, N. (1989) 'Life-cycle of technology and commercial policy', Science \& Technology Review, Vol. 1, pp.38-43.

Leiblein, M.J. and Miller, D.J. (2003) 'An empirical examination of transaction-and firm-level influences on the vertical boundaries of the firm', Strategic Management Journal, Vol. 24, No. 9, pp.839-859.

Lilischkis, S. (2013) Policies for High Growth Innovative Enterprises, Report on the 2013 ERAC Mutual Learning Seminar on Research and Innovation Policies.

Lin, Z., Yang, H. and Arya, B. (2009) 'Alliance partners and firm performance: resource complementarity and status association', Strategic Management Journal, Vol. 30, No. 9, pp.921-940.

Linden, A. and Fenn, J. (2003) Understanding Gartner's Hype Cycles, Strategic Analysis Report No. R-20, Gartner.

Lioukas, C.S., Reuerand, J.J. and Zollo, M. (2016) 'Effects of information technology capabilities on strategic alliances: implications for the resource-based view', Journal of Management Studies, Vol. 53, No. 2, pp.161-183.

Little, A.D. (1981) The Strategic Management of Technology, European Management Forum, Gartner, Inc., Davos.

Luca, L.M.D. and Atuahene-Gima, K. (2007) 'Market knowledge dimensions and cross-functional collaboration: examining the different routes to product innovation performance', Journal of Marketing, Vol. 71, No. 1, pp.95-112.

Madhok, A. (1997) 'Cost, value and foreign market entry mode: the transaction and the firm', Strategic Management Journal, Vol. 18, No. 1, pp.39-61.

Masten, S.E., Meehan, J.W. and Snyder, E.A. (1991) 'The costs of organization', Journal of Law, Economics, and Organization, Vol. 7, No. 1, pp.1-25.

Mayer, K.J. and Argyres N.S. (2004) 'Learning to contract: evidence from the personal computer industry’, Organization Science, Vol. 15, No. 4, pp.394-410.

Mayer, K.J. and Nickerson, J.A. (2005) 'Antecedents and performance implications of contracting for knowledge workers: evidence from information technology services', Organization Science, Vol. 16, No. 3, pp.225-242.

McGrath, R.G. and MacMillan, I.C. (2000) The Entrepreneurial Mindset: Strategies for Continuously Creating Opportunity in an Age of Uncertainty, Harvard Business Press. Boston, USA.

McIvor, R. (2009) 'How the transaction cost and resource-based theories of the firm inform outsourcing evaluation', Journal of Operations Management, Vol. 27, No. 1, pp.45-63.

Meier, M., Lütkewitte, M., Mellewigt, T. and Decker, C. (2016) 'How managers can build trust in strategic alliances: a meta-analysis on the central trust-building mechanisms', Journal of Business Economics, Vol. 86, No. 3, pp.229-257.

Merton, R., Fiske, M. and Kendall, P. (1990) The Focused Interview: A Manual of Problems and Procedures, 2nd ed., The Free Press, New York.

Mitchell, W. and Parmigiani, A. (2009) 'Complementarity, capabilities, and the boundaries of the firm: the impact of within-firm and interfirm expertise on concurrent sourcing of complementary components', Strategic Management Journal, Vol. 30, No. 10, pp.1065-1091.

Monteverde, K. (1995) 'Technical dialog as an incentive for vertical integration in the semiconductor industry', Management Science, Vol. 41, No. 10, pp.1624-1638.

Moore, G. (2002) Crossing the Chasm, Harper Business, New York, NY.

Moore, G.A. (1998) Inside the Tornado, Harper Business, New York, NY. 
Moore, G.A. (2011) Escape Velocity: Free Your Company's Future from the Pull of the Past, Harper Business, New York, NY.

Mowery, D.C. and Rosenberg, N. (1989) 'New developments in US technology policy: implications for competitiveness and international trade policy', California Management Review, Vol. 32, No. 1, p.107.

Mui, C. (2012) How Kodak Failed, Forbes, 18.1.2012 [online] http://www.forbes.com/sites/ chunkamui/2012/01/18/how-kodak-failed/\#246ad827bd6a (accessed 19 October 2016).

Murmann, J.P. and Frenken, K. (2006) 'Toward a systematic framework for research on dominant designs, technological innovations, and industrial change', Research Policy, Vol. 35, No. 7, pp.925-952.

Nelson, R.R. and Winter, S.G. (2009) An Evolutionary Theory of Economic Change, Harvard University Press, Boston, MA.

Ng, W.K., Zillante, G., Chan, A.P.C., Zuo, J. and Xia, B. (2012) 'Selection of project procurement methods in the consumer electronics industry: a Hong Kong study', International Journal of Procurement Management, Vol. 5, No. 3, pp.289-315.

Nickerson, J.A. and Zenger, T.R. (2004) 'A knowledge-based theory of the firm-the problemsolving perspective', Organization Science, Vol. 15, No. 6, pp.617-632.

Nyberg, A.J., Moliterno, T.P., Hale, D. and Lepak, D.P. (2014) 'Resource-based perspectives on unit-level human capital a review and integration', Journal of Management, Vol. 40, No. 1, pp.316-346.

O'Reilly, C.A. and Tushman, M.L. (2013) 'Organizational ambidexterity: past, present, and future', The Academy of Management Perspectives, Vol. 27, No. 4, pp.324-338.

Olk, P. and Young, C. (1997) 'Why members stay in or leave an R\&D consortium: performance and conditions of membership as determinants of continuity', Strategic Management Journal, Vol. 18, No. 11, pp.855-877.

Oster, S.M. (1990) Modern Competitive Analysis, Oxford University Press, New York, NY.

Oumlil, A.B. and Williams, A.J. (2011) 'Strategic alliances and organisational buying: an empirical study of the healthcare industry', International Journal of Procurement Management, Vol. 4, No. 6, pp.610-626.

Park, H., Sung, T. and Kim, S. (2015) 'Strategic implications of technology life-cycle on technology commercialization', Proceedings of the International Association for Management of Technology, IAMOT 2015, pp.2736-2748.

Parkhe, A. (1991) 'Interfirm diversity, organizational learning, and longevity in global strategic alliances', Journal of International Business Studies, Vol. 22, No. 4, pp.579-601.

Parkhe, A. (1993) 'Strategic alliance structuring: a game theoretic and transaction cost examination of interfirm cooperation', Academy of Management Journal, Vol. 36, No. 4, pp.794-829.

Patzelt, H., Shepherd, D.A., Deeds, D. and Bradley, S.W. (2008) 'Financial slack and venture managers' decisions to seek a new alliance', Journal of Business Venturing, Vol. 23, No. 4, pp.465-481.

Peteraf, M.A. (1993) 'The cornerstones of competitive advantage: a resource-based view', Strategic Management Journal, Vol. 14, No. 3, pp.179-191.

Poppo, L. and Zenger, T. (1998) 'Testing altermative theories of the firm: transaction cost, knowledge-based, and measurement explanations for make-or-buy decisions in information services, Strategic Management Journal, Vol. 19, No. 9, pp.853-877.

Powell, W.W., Koput, K.W. and Smith-Doerr, L. (1996) 'Interorganizational collaboration and the locus of innovation: networks of learning in biotechnology', Administrative Science Quarterly, Vol. 41, No.1, pp.116-145.

Proctor, T. (2014) Strategic Marketing: An Introduction, Routledge, London.

Quinn, J.B. (2013) 'Strategic outsourcing: leveraging knowledge capabilities', Image, Vol. 34, pp.9-21. 
Ramanathan, K., Seth, A. and Thomas, H. (1997) 'Explaining joint ventures: alternative theoretical perspectives', Cooperative Strategies, Vol. 1, pp.51-85.

Rita, P. and Krapfel, R. (2015) Collaboration and Competition in Buyer-Supplier Relations: The Role of Information in Supply Chain and e-Procurement Impacted Relationships, in Assessing the Different Roles of Marketing Theory and Practice in the Jaws of Economic Uncertainty, pp.98-105, Springer, Cheltenham, England.

Roberts, E.B. and Berry, C.A. (1984) Entering New Businesses: Selecting Strategies for Success, Massachusetts Institute of Technology, Cambridge, Massachusetts.

Rogers, E.M. (2010) Diffusion of Innovations, Free Press, New York, NY.

Rossi, C., Cricelli, L., Grimaldi, M. and Greco, M. (2016) 'The strategic assessment of intellectual capital assets: an application within Terradue Srl', Journal of Business Research, Vol. 69, No. 5, pp.1598-1603.

Rothaermel, F.T. and Deeds, D.L. (2006) 'Alliance type, alliance experience and alliance management capability in high-technology ventures', Journal of Business Venturing, Vol. 21, No. 4, pp.429-460.

Routley, M., Phaal, R. and Probert, D. (2013) 'Exploring industry dynamics and interactions', Technological Forecasting and Social Change, Vol. 80, No. 6, pp.1147-1161.

Rumelt, R.P. (1995) Inertia and Transformation, Springer, Berlin.

Schoenberg, R. (2001) 'Knowledge transfer and resource sharing as value creation mechanisms in inbound continental European acquisitions', Journal of Euromarketing, Vol. 10, No. 1, pp.99114.

Schwarz, A., Jayatilaka, B., Hirschheim, R. and Goles, T. (2009) 'A conjoint approach to understanding IT application services outsourcing', Journal of the Association for Information Systems, Vol. 10, No. 10, pp.748-781.

Seifert, R.W., Tancrez, J-S. and Biçera, I. (2015) 'Dynamic product portfolio management with life cycle considerations', International Journal of Production Economics, Vol. 171, Part 1, No. 1, pp.71-83.

Sharma, A. and Jha, S. (2016) 'Innovation from emerging market firms: what happens when market ambitions meet technology challenges?', Journal of Business \& Industrial Marketing, Vol. 31, No. 4, pp.507-518.

Sharma, K.S. (2016) 'Risk adjusted total cost of ownership model for strategic sourcing decisions', International Journal of Procurement Management, Vol. 9, No. 2, pp.123-145.

Shih, W. (2016) 'The real lessons from Kodak's decline', MIT Sloan Management Review, Vol. 57, No. 4, pp.11-13.

Siggelkow, N. (2007) 'Persuasion with case studies', Academy of Management Journal, Vol. 50, No. 1, pp.20-24.

Søndergaard, E.S. and Ahmed-Kristensen, S. (2015) 'Decision making processes for global product development - a case study', Proceedings of the 22nd Innovation and Product Development Management Conference, European Institute for Advanced Studies in Management, Twente University, pp.1-20.

Spithoven, A. and Teirlinck, P. (2015) 'Internal capabilities, network resources and appropriation mechanisms as determinants of R\&D outsourcing', Research Policy, Vol. 44, No. 3, pp.711725 .

Stettner, U. and Lavie, D. (2014) 'Ambidexterity under scrutiny: exploration and exploitation via internal organization, alliances, and acquisitions', Strategic Management Journal, Vol. 35, No. 13, pp.1903-1929.

Suarez-Villa, L. and Rama, R. (1996) 'Outsourcing, R\&D and the pattern of intra-metropolitan location: the electronics industries of Madrid', Urban Studies, Vol. 33, No. 7, pp.1155-1197.

Sucky, E. and Durst, S.M. (2013) 'Supplier development: current status of empirical research', International Journal of Procurement Management, Vol. 6, No. 1, pp.92-127. 
Sundquist, V., Hulthén, K., Gadde, L-E. (2016) 'Economic consequences of alternative make-orbuy configurations', Industrial Marketing Management, Vol. 46, No. 11, pp.98-107.

Sveiby, K. (2001) 'A knowledge-based theory of the firm to guide in strategy formulation', Journal of Intellectual Capital, Vol. 2, No. 4, pp.344-358.

Teece, D.J., Pisano, G. and Shuen, A. (1997) 'Dynamic capabilities and strategic management', Strategic Management Journal, Vol. 18, No. 7, pp.509-533.

Tolonen, A., Harkonen, J., Verkasalo, M. and Haapasalo, H. (2015a) 'Product portfolio management process over horizontal and vertical portfolios', International Journal of Product Lifecycle Management, Vol. 8, No. 3, pp.189-215.

Tolonen, A., Shahmarichatghieh, M., Harkonen, J. and Haapasalo, H. (2015b) 'Product portfolio management - targets and key performance indicators for product portfolio renewal over life cycle', International Journal of Production Economics, Vol. 170, Part B, pp.468-477.

Torvinen, P., Podmetina, D., Hinkkanen, J. and Väätänen, J. (2014) 'External technology acquisition in Russian firms', International Journal of Procurement Management, Vol. 7, No. 3, pp.257-278.

Tyler, B.B. and Steensma, H.K. (1998) 'The effects of executives' experiences and perceptions on their assessment of potential technological alliances', Strategic Management Journal, Vol. 19, No. 10, pp.939-965.

Watts, R.J. and Porter, A.L. (1997) 'Innovation forecasting', Technological Forecasting and Social Change, Vol. 56, No. 1, pp.25-47.

Wei, J., Waiker, G. and Kogut, B. (2000) 'Interfirm cooperation and startup innovation in the biotechnology industry', Strategic Management Journal, Vol. 15, No. 5, pp.387-394.

Wieland, H., Vargo, S.L. and Akaka, M.A. (2016) 'Zooming out and zooming in: service ecosystems as venues for collaborative innovation', service innovation, in Toivonen, M. (Ed.): Translational Systems Sciences, Vol. 6, pp.35-50.

Williamson, O.E. (1975) Markets and Hierarchies, Analysis and Antitrust Implications: A Study in the Economics of Internal Organization, Free Press, New York, NY.

Williamson, O.E. (1979) 'Transaction -cost economics: the governance of contractual relations', The Journal of Law \& Economics, Vol. 22, No. 2, pp.233-261.

Williamson, O.E. (1981) 'The economics of organization: the transaction cost approach', American Journal of Sociology, Vol. 87, No. 3, pp.548-577.

Williamson, O.E. (1983) 'Credible commitments: using hostages to support exchange', The American Economic Review, Vol. 73, No. 4, pp.519-540.

Williamson, O.E. (1991) 'Comparative economic organization: the analysis of discrete structural alternatives’, Administrative Science Quarterly, Vol. 36, No. 2, pp.269-296.

Wilson, B.D. (1980) 'The propensity of multinational companies to expand through acquisitions', Journal of International Business Studies, Vol. 11, No. 1, pp.59-65.

Yap, C.S., Lim, Y.M., Jalaludin, F.W. and Lee, T.H. (2016) 'Determinants of ICT outsourcing among the locally-owned manufacturers in Malaysia', Strategic Outsourcing: An International Journal, Vol. 9, No. 3.

Yin, R.K. (2003) Case Study Research: Design and Methods, 3rd ed., Sage Publications, Thousands Oaks, California.

Yip, G.S. (1982) 'Diversification entry: internal development versus acquisition', Strategic Management Journal, Vol. 3, No. 4, pp.331-345.

Yoshino, M.Y. and Rangan, U.S. (1995) Strategic Alliances: An Entrepreneurial Approach to Globalization, Harvard Business Press, Boston, MA.

Young-Ybarra, C. and Wiersema, M. (1999) 'Strategic flexibility in information technology alliances: the influence of transaction cost economics and social exchange theory', Organization Science, Vol. 10, No. 4, pp.439-459.

Zejan, M.C. (1990) 'New ventures or acquisitions. The choice of Swedish multinational enterprises', The Journal of Industrial Economics, Vol. 38, No. 3, pp.349-355. 
Zhang, J., Hoenig, S., Di Benedetto, A., Lancioni, R.A. and Phatak, A. (2009) 'What contributes to the enhanced use of customer, competition and technology knowledge for product innovation performance? : A survey of multinational industrial companies' subsidiaries operating in China', Industrial Marketing Management, Vol. 38, No. 2, pp.207-218.

Zhao, Y., Cavusgil, E. and Cavusgil, S.T. (2014) 'An investigation of the black-box supplier integration in new product development', Journal of Business Research, Vol. 67, No. 6, pp.1058-1064. 